\title{
Correction: Metabolomics of World Trade Center-Lung Injury: a machine learning approach
}

Crowley G, Kwon S, Haider SH, et al. Metabolomics of World Trade Center-Lung Injury: a machine learning approach. BMJ Open Resp Res 2018;5:e000274. doi: 10.1136/ bmjresp-2017-000274

The authors would like to alert the readers on the incorrect affiliations for the last three co-authors of this paper. The information is now updated in the online version and is stated below:

George Crowley, ${ }^{1}$ Sophia Kwon, ${ }^{1}$ Syed Hissam Haider, ${ }^{1}$ Erin J Caraher, ${ }^{1}$ Rachel Lam, ${ }^{1}$ David E St-Jules, ${ }^{2}$ Mengling Liu, ${ }^{3,5}$ David J Prezant, ${ }^{4,6}$ Anna Nolan ${ }^{1,3,4}$

${ }^{1}$ Department of Medicine, Division of Pulmonary, Critical Care and Sleep Medicine, New York University School of Medicine, New York, USA.

${ }^{2}$ Departmentof Population Health, Division of Health and Behavior, New York University School of Medicine, New York, USA.

${ }^{3}$ Department of Environmental Medicine, New York University School of Medicine, New York, USA.

${ }^{4}$ Bureau of Health Services and Office of Medical Affairs, Fire Department of New York, Brooklyn, New York, USA.

${ }^{5}$ Department of Population Health, Division of Biostatistics, New York University School of Medicine, New York, USA.

${ }^{6}$ Department of Medicine, Pulmonary Medicine Division, Montefiore Medical Center and Albert Einstein College of Medicine, Bronx, New York, USA.

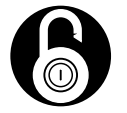

\section{OPEN ACCESS}

Open access This is an open access article distributed in accordance with the Creative Commons Attribution Non Commercial (CC BY-NC 4.0) license, which permits others to distribute, remix, adapt, build upon this work non-commercially, and license their derivative works on different terms, provided the original work is properly cited, appropriate credit is given, any changes made indicated, and the use is non-commercial. See:http://creativecommons.org/licenses/by-nc/4.0

(c) Author(s) (or their employer(s)) 2018. Re-use permitted under CC BY-NC. No commercial re-use. See rights and permissions. Published by BMJ.

BMJ Open Resp Res 2018;5:e000274corr1. doi:10.1136/bmjresp-2017-000274corr1

Check for updates 